Nevşehir Bilim ve Teknoloji Dergisi Cilt 6(ICOCEE 2017 Özel Sayı) 349-361 2017

DOI: 10.17100/nevbiltek.320096

URL: http://dx.doi.org/10.17100/nevbiltek.320096

A Study on the Calculation of the Material Cost for Old Structures;

Mimar Sinan Kurşunlu Mosque

\author{
Z. Özlem PARLAK BIÇER* , Hürmet ÇOPUROĞLU, Merve HASÖZHAN, Zehra AKSOY \\ Erciyes Üniversitesi, Mimarlık Fakültesi, Mimarlık Bölümü, Kayseri
}

\begin{abstract}
Financing and management of the project are primary requisites for carrying out construction work. The most apparent input affecting the cost of a structure is considered as the material. This can be observed in all structures from examples of civil architecture to monumental structures. Structures by Mimar Sinan have a special place among monumental structures. Kurşunlu Mosque which is one of the late period structures by Mimar Sinan is one of the more modest structures built upon the approval by Sinan. Even though there are some debates regarding the inclusion of Sinan in planning and construction works, it is pointed out among his works since the architectural patterns reflect those of his style. In this study; Kurşunlu Mosque of Sinan was examined with regard to calculations regarding material cost for historical monumental structures. Afterwards; the cost of the stone which was the main material used in the construction of the Kurşunlu Mosque was calculated using unit prices of our day. $t$ is exemplary for the architects of our day that Sinan who is the most important architect of all ages has used local materials in one of his late period works for decreasing the cost. It is hoped that the study will form a basis for and contribute to future studies on materials and cost.
\end{abstract}

Keywords: Architect Sinan, Kurşunlu Mosque, Kayseri, Cost Analysis

\title{
Geleneksel Yapı Malzemeleri Üzerinden Maliyet Hesaplama; Mimar Sinan Kurşunlu Cami
}

$\ddot{\text { Ozz }}$

Yapı işinin gerçekleşebilmesi için gerekli olanların başında projenin finansmanı ve yönetimi önemli olmaktadır. Yapının maliyetini etkileyen en belirgin girdi ise malzeme olarak görülmektedir. Sivil mimarlık örneklerinden anıtsal yapılara kadar bu durum gözlemlenebilir. Anıtsal yapılar içerisinde ise Mimar Sinan'ın yapılarının yeri tartışılamazdır. Mimar Sinan'ın son dönem yapılarından olan Kurşunlu Cami de Sinan'ın izni ile yapıldığı bilinen küçük ölçekli, Sinan'ın büyüklüğüne rağmen mütevazı yapılardan biridir. Birebir plan ve yapım işlerinde Sinan'ın bulunması konusunda tartışmaları olsa da Sinan'ın yetki dönemi içerisinde yapılması ve onun mimari çizgilerini yansıtan diğer yapılarına benzemesi açısından onun eserleri arasında gösterilmektedir. Bu yapının seçilmesinde yapının ünlü bir mimarın ustalık dönemlerinde yaptığı anıtsal yapı olmasının ve buna karşın boyut olarak diğer anıtsal yapılara göre daha mütevazı olmasının etkisi vardır. Bu çalışmada; öncelikle Mimar Sinan ve mesleki dönemlerini temsil eden yapıtları anlatılmaya çalışılmıştır. Kurşunlu Cami’nin yapımında ana malzeme olan taşın maliyeti, günümüz birim fiyatları ile hesaplanmıştır. Daha sonra son önem eserlerinden olan Kurşunlu Cami ele alınmış ve caminin yapı malzemesi olan taşın maliyeti çıkarılmıştır. Tüm çağların büyük mimarı olan Sinan'ın son dönem eserinde malzeme açısında yereli kullanması ve maliyeti düşünmesi, günümüz mimarları için de örnek teşkil etmektedir. Çalışmanın özellikle malzeme ve maliyet alanda yapılacak çalışmalara temel olması ve katkı sağlaması umulmaktadır.

Anahtar Kelimeler: Mimar Sinan, Kurşunlu Cami, Kayseri, Maliyet Analizi

*e-mail: parlakoz@yahoo.com 


\section{Introduction}

Construction cost has formed the foundation of the planning for the building production process. Knowing beforehand the cost of the structure during each period is an important factor for the production process. In this study; the cost of Kurşunlu Mosque which is one of the structures by Mimar Sinan was handled with regard to the conditions of our day excluding labor cost.

Cost estimation in the construction sector is mostly one of the most important factors affecting decisions regarding the continuation of the construction period. The fundamental goal of cost estimation is to provide reliable information about the possible costs while drawing the main outline of the project idea thereby helping in giving decisions about the pre-planning period. Hence; knowing the costs beforehand has always been an important issue for making correct budgetary organizations by providing the means to plan and control costs during the project and construction phases. Based on this, cost estimations made during the design and planning stages make up one of the most important lines as to whether the project should be actualized or not. It has always been important to know in advance the cost of structures throughout history as well as in our day [1].

During the Ottoman period, construction costs were determined beforehand and the costs related with repair and new building works were estimated using a cost estimation method known as Karname which was based on approximate cost calculations using quantity information as well as projects drawn on plotting papers and taking into consideration the unit prices. In this regard, no construction work was allowed during the Ottoman period if the cost was not known beforehand. The reason for this was to guarantee the investment while also providing transparency and preventing possible exploitations [1].

In this paper, the approximate cost calculations and cost for the repair and building works for the Kurşunlu Mosque which is one of the important structures of the Ottoman period were examined via the methods and unit prices used today.

The word mosque means that which gathers and brings together. In this regard, it is the sanctuary where Muslims gather together for worship. The word mescit is used in the first historical sources instead of the word mosque. Whereas mescit is the name given to the location where muslims "kotow" during prayer. It can roughly be stated that mescits are constructed in neighborhoods, mosques in districts and grand mosques in cities [2].

Many different types of structures were constructed during the transformation of the Ottoman from chiefdom to kingdom in order to meet the demands of the society. Mosques which are indicators of the economic wealth of the state as well as a religious symbol stand out among these architectural works. When the mosques of the Ottoman era are examined, it is clear that there has been a period of development in terms of architecture reaching its pinnacle with the contributions of Mimar Sinan. In this study, the Kurşunlu Mosque that is among the Classical Ottoman Architecture examples which is thought to have been built by Mimar Sinan has been taken into consideration.

\section{Life and Works of Mimar Sinan}

Son of Abdülmennan, Sinan was born at the Ağırnas Village of Kayseri but his date of birth is not known for sure. However, majority of the opinions indicate the birth year as 1489 . He was taken into the Guild of Janissaries as a devshirme during the reign of Yavuz Sultan Selim. Sinan took part in many 
military expeditions together with Yavuz Sultan Selim and Kanuni Sultan Süleyman but his rise in the field of military is thought to be due more to his craftsmanship rather than military skills. Mimar Sinan lived during a period of time when the Ottoman Empire reigned the largest plots of land and he was appointed as chief architect when Alaeddin known asArchitect Acem Ali passed away in 1539. Kanuni Sultan Süleyman worked as the chief architect during the reign of Selim the 2ndand Murad the 3rd thus playing a major role in the design and construction of architectural masterpieces that symbolize the power of the empire. He is known as "Mimar Sinan", "Chief Architect Mimar" and "Koca Sinan" due to his contributions to architecture as well as the expert solutions he put forth especially for dome architecture during a time when technical abilities were very limited [3].

Sinan passed away in 1588 leaving behind many mosques built during the Ottoman empire for a total of 375 works comprised of 81 Mosques, 51 mescits, 55 medrasahs, 26 darül-kurra, 17 mausoleums, 17 almshouses, 3 hospitals, 5 aqueducts, 8 bridges, 20 caravanserais, 36 palaces, 8 cisterns and 48 Turkish baths [2]. However, his greatest desire was to build a bright and spacious mosque with full unity of space that encompassed the congregation much like the sky. The hills reigned supreme over the city with social complexes including mosques. His first important work was the Şehzade Mosque in Istanbul. He has characterized this as the work during his apprenticeship period. Süleymaniye Mosque which was built during his qualification period. Selimiye Mosque in Edirne was defined by him as a master stage work [4].

In this study, the three works characterized by Sinan as works of apprenticeship, qualification and master stage works were taken into consideration and the mosque typology was examined. Among these, Kurşunlu Mosque which corresponds to the Ottoman classical period was examined with regard to material cost.

\section{1 Şehzade Mosque Structural and Spatial Analysis}

Şehzade Mosque located at the Fatih District, Laleli Quarter of Istanbul was the first step of the three main stages of the architectural genius of Mimar Sinan (Photograph I). Şehzade Mosque was ordered to be built in 1543 by Kanuni Sultan Süleyman in the name of his son Şehzade Mehmet who passed away when he was 22 and there is a mausoleum in the garden of the mosque for Shehzade Mehmet.Whereas the mausoleums of the other princes are located at the Vefa section of the social complex.Medrasah, soup kitchen, tabhane and mausoleums are located in the garden of the mosque and on the rear street. Şehzade Mosque which is one of the most beautiful works of art by Mimar Sinan which he characterizes as one of his apprenticeship stage pieces was completed in 1548 within a period of 4 years. Şehzade Mosque is also the first monumental structure within the Ottoman Classical Architecture [5].

Şehzade Külliye has been built on a large block. It is separated from the environment with a high stone wall and there is mosque at the center of the outer courtyard. The mosque has a square form (Drawings 1-2-3). There is a central dome with a diameter of 18.42right at the center of this square plot of land. This dome is carried by four main crowns on which four semi-domes rest. This four semi-dome mosque type that was to be applied in many mosques later on was first tried for the Şehzade Mosque. 
This structural plan was later used in the Eminönü Yeni Valide Mosque, Sultanahmet Mosque ve Fatih Mosques [6].

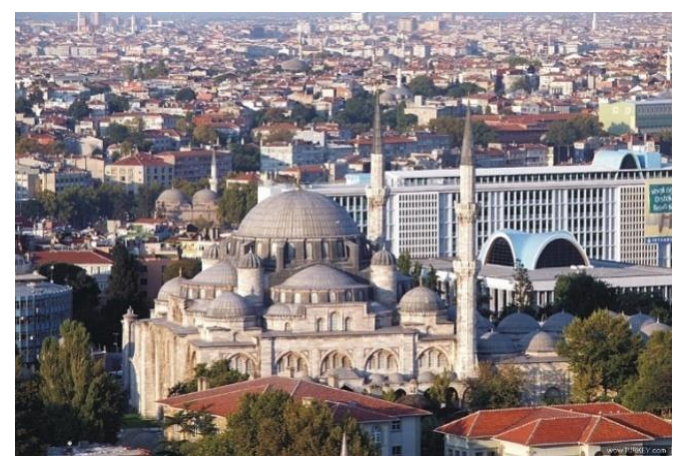

Photograph 1. Şehzade Mosque [7]

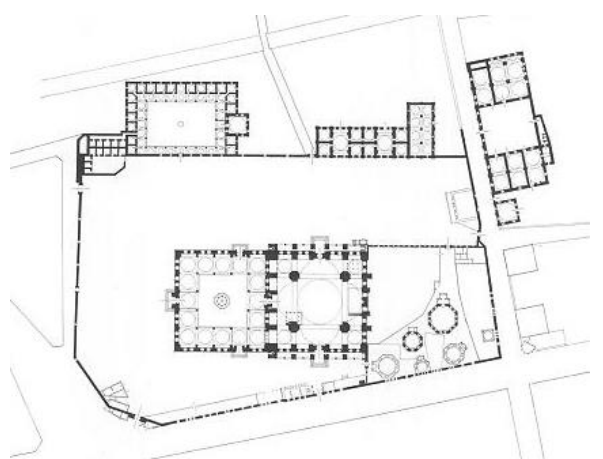

Drawing 1. Şehzade Külliye Plan [8]

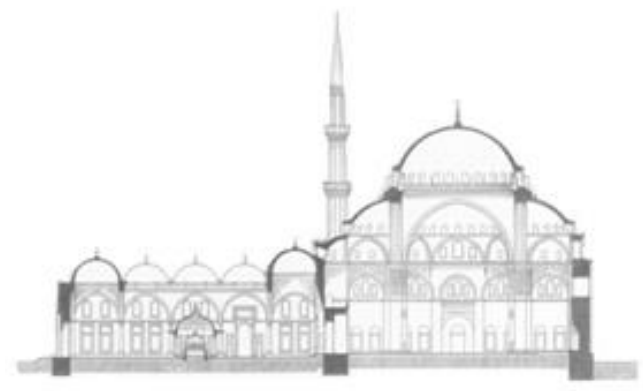

Drawing 2. Şehzade MosqueCross Section [9]

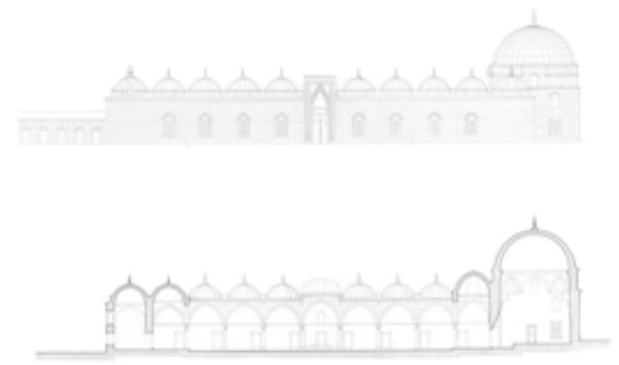

Drawing 3. Şehzade Külliye Cross Section and Appearance [8]

\subsection{Süleymaniye Mosque Structural and Spatial Analyses}

Süleymaniye Mosque is located at the city of Istanbul in Turkey, Fatih District, Süleymaniye quarter. The mosque was ordered by Mimar Sinan during the 16th century in the name of by Kanuni Sultan Süleyman who was the ruler at the time. The construction work was started in 1550 and was completed in 7 years. Süleymaniye Mosque is one of the qualification stage works by Mimar Sinan and is one of the most important examples of Classical Period Ottoman Architecture (Photograph 2). Many structures were built around the Süleymaniye Mosque located at the center of the külliye. Kanuni and Hürrem mausoleums, medrasahs providing education at different levels, a hadith school, a school of medicine, elementary school, hospital, guesthouse, a structure for Qur'an education, a souphouse called imaret, Turkish bath, inn, library, Sinan's mausoleum and many shops (Drawing 4).

Süleymaniye Mosque has been built on four pillars calculated to be 30 tons each (Drawing 5). The main dome and upper masonry shell transfer the weight of about 1000 tons to the foundation via two semi-domes and the pillars [12]. There are four main arches between the pillars. "The main arches have been constructed without tie rods. However, tension has been used for the smaller arches at the clearances between the primary semi-domes and secondary semi-domes for the structure that covers the central inner space of the Süleymaniye Mosque" [10].

The main dome of the mosque is located above the main arches and fil ayakları. There is a total of 32 windows on the dome frame. Two semi-domes support the main dome from the sides. The semi- 
domes are supported by two smaller domes each which are called exedra. There are five domes of various sizes at sections where there are no semi-domes. In addition, there are twenty eight small domes at the courtyard [11].

There are four minarets in the mosque. The reason for this is that Kanuni Sultan Süleyman was the 4th Ottoman Sultan following the conquest of Istanbul. These minarets are located at the four corners of the courtyard. The total of ten minaret balconies on the four minarets symbolize that Kanuni Sultan Süleyman is the tenth Ottoman sultan (Drawing 6) [11].

The structure has been able to preserve its mass integrity apart from various additions built during different periods of time. The library below the mahfil (gathering place) for women to the right of the mihrab axis is one of the most important additions. Decisions were made in 1940 regarding the location of the last position for the congregation in the mosque [10]. The mosque is almost completely symmetrical to the Kaaba axis and is almost symmetrical in the perpendicular axis [11].

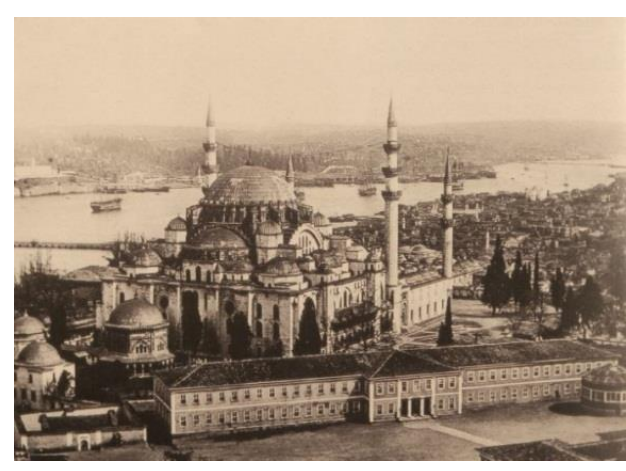

Photograph 2. Süleymaniye Mosque [12]

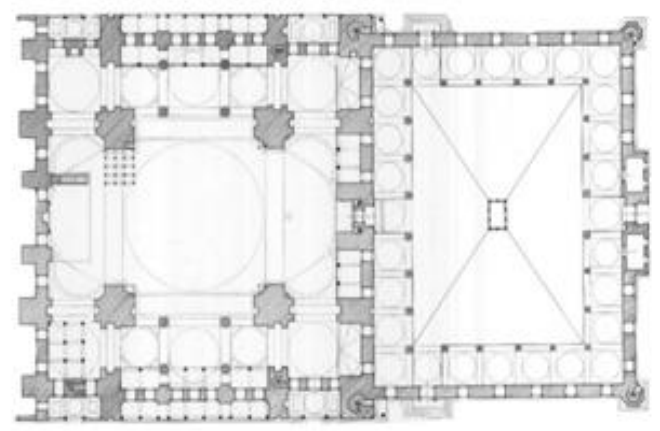

Drawing 5. Süleymaniye Mosque Ground Floor Plan [11]

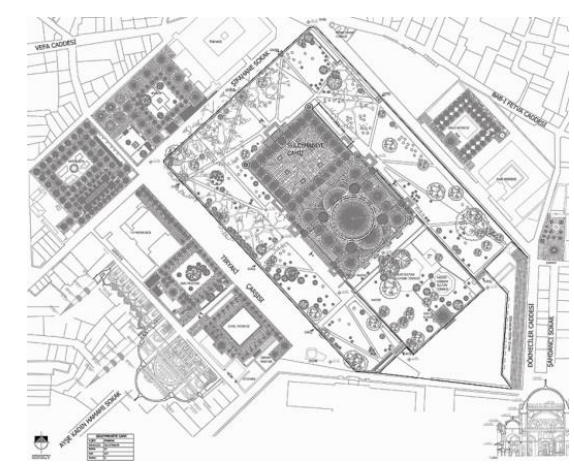

Drawing 4. Süleymaniye Mosque Layout Plan [12]

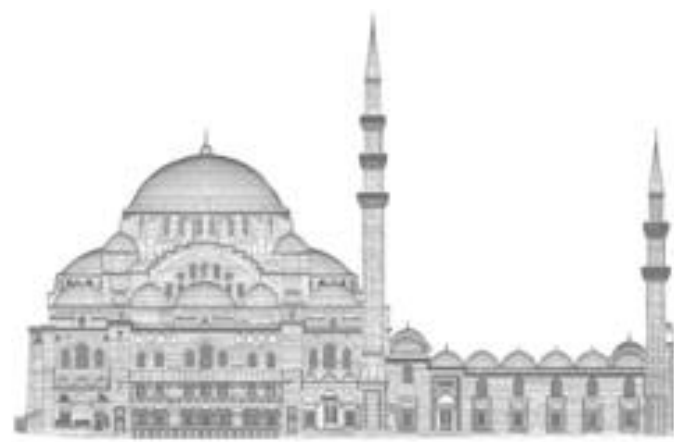

Drawing 6. Süleymaniye Mosque Northeast Façade Survey [11]

\subsection{Selimiye Mosque Structural and Spatial Analyses}

The monumental structure built by Mimar Sinan at age 80 which he characterized as "my master stage work" is one of the masterpieces of the Ottoman-Turkish art and history of world architecture. The ownership of the structure is held by the Sultan Selim Association at the Edirne-Centrum Yeni Quarter (Photograph-3) [14]. It is not known for certain the date when the construction for the Selimiye Mosque was started. However, it has been recorded in the mosque tablet located on the Selimiye Mosque door that the construction work was started in 1568. The mosque, madrasah and Dar-ül Hadis have been placed in a symmetrical manner inside the 190x130 meter courtyard with the mosque at the center and the twin 
educational structures at the corners (Drawing 7). It attracts attention with its four minarets that attract attention from a distance. Thus, Selimiye is a work of art indicating that Mimar Sinan was also an expert in town planning in addition to being a great architect [13].

Selimiye Mosque has made architectural history as the widest mosque covering an area of 22202 $\mathrm{m}^{2}$ encompassing an area of $2475 \mathrm{~m}^{2}$ in total and an interior area of $1.575 \mathrm{~m}^{2}$. Dârü'lkurrâ and the madrasah have been placed at the two southern corners of the mosque placed on a platform. This structure that can be seen from anywhere in Edirne takes on a breathtaking appearance as one approaches the city.

The walls are made of cut stone. The mosque located at the center of a courtyard surrounded by walls is comprised of a praying area with a length of about 40 meters and width of 60 meters along with a şadırvan (courtyard with a fountain) that has almost the same dimensions [13]. The mosque built of cut stone covers an area of $1.620 \mathrm{~m}^{2}$ with its inner section and $2.475 \mathrm{~m}^{2}$ in whole. Selimiye Mosque is characterized as a structure that has been built on the widest area of land in architectural history and attracts attention with its dome that has a height of $43.28 \mathrm{~m}$. and a diameter of $31.30 \mathrm{~m}$. The dome rests on 8 large pedestals connected together by $6 \mathrm{~m}$ wide arches. Four semi-domes at the corners and one semidome at the mihrab support the central dome [14].

It has four minarets. The harmonious appearance of the four minarets with balconies located at the four corners of the large dome of Selimiye is worth seeing. These four minarets have been placed symmetrically so that they appear as two minarets when seen from the entrances to the city of Edirne. Sinan has been able to combine 4 minarets with a single dome without using separate domes and als succeeded in ensuring both a nice appearance as well as a structural balance (Drawing 8).

The outer courtyard of Selimiye surrounds the mosque from three sides. Dar-ül Kur-a and Dar-ül Hadith structures are located in the wide outer courtyard of the Selimiye Mosque surrounded by stone walls. The number of garden gates is eight. The mosque has four gates including the large entrance gate to the west. The most glorious of the gates opening onto the courtyard looks west. These gates have exquisite decorations and are porphyritic. The surface is white marble. The door wings are interlocking. The mirrors are very elegant and rich. The tablet at the top of the central gate indicating the dates of mounting and completion is striking. Whereas the courtyard with a fountain has a rectangular plan. Porticos covered with domes surround the courtyard. The porticos are in total 18 domes over 16 columns (Drawing 9). The columns have been built as single piece [13].

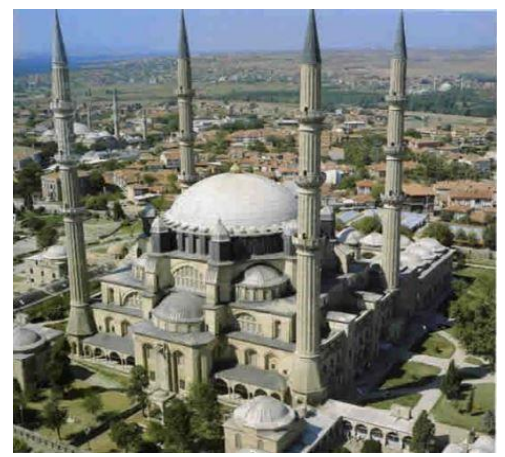

Photograph-3. Edirne Selimiye Mosque [14]

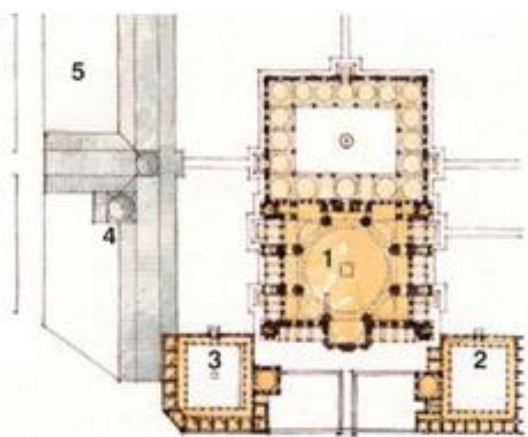

Drawing-7. Edirne Selimiye Mosque and Külliye Plan [14] 


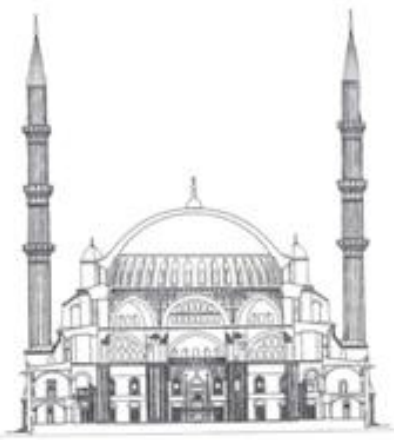

Drawing-8. Edirne Selimiye Mosque Cross Section [14]

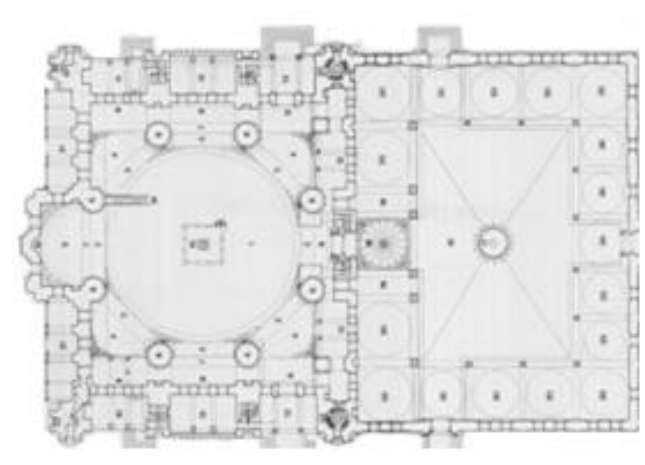

Drawing-9. Edirne Selimiye Mosque Plan [13]

\subsection{Kurşunlu Mosque Structural and Spatial Analyses}

It is located inside the Mimar Sinan Park to the west of the Cumhuriyet Square at the Kocasinan district in the city of Kayseri. Its plan typology is similar to those of the Bali Paşa Mosque and Hadım İbrahim Paşa Mosque which are Beyazit the Second period structures. In this regard, it is considered to be a Mimar Sinan structure. Kurşunlu Mosque is the only structure by Mimar Sinan that has reached our day from among the two mosques built by him in Kayseri (Photograph 4, Drawing10). The structure that has taken its current name from the lead coating of its dome is also known as Hacı Ahmet Paşa Mosque. The tablet of the structure bears the dates of 1585-1586. However, it is indicated in the letter of conveyance issued for Ahmet Paşa by Selim the 2nd that this mosque is dated August 1573 [15].

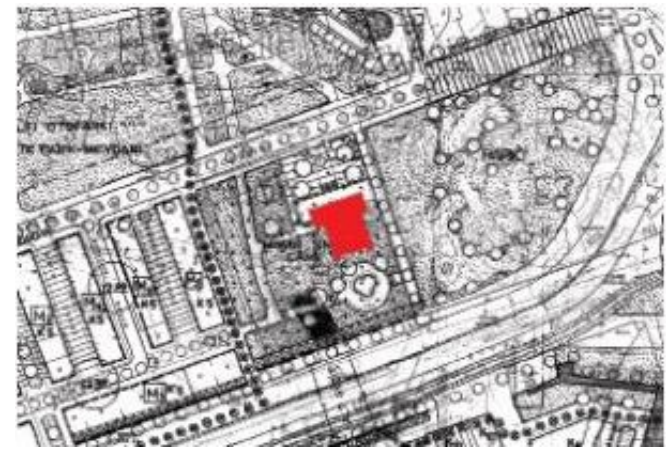

Drawing 10. Kurşunlu Mosque Layout Plan [15]

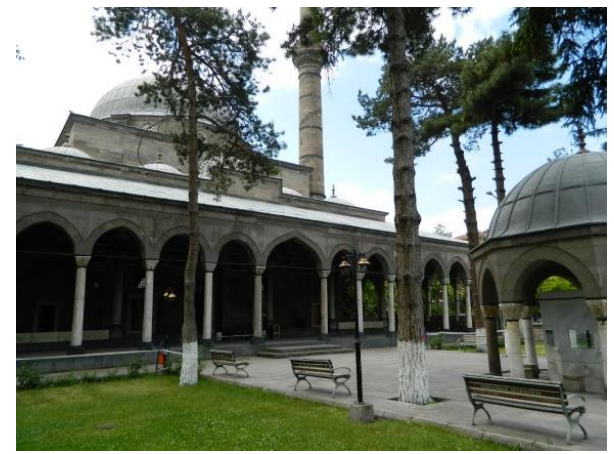

Photograph-4. Kurşunlu Mosque Courtyard [15]

The mosque is the only structure that has reached our day from the Hacı Ahmet Paşa Külliye comprised of imaret, inn, school and Turkish bath and consists of a single site sanctuary covered with a dome and the narthex at the north façade. The dome that covers up the single site rests on the feet at the corners and pendentives are used to support the dome (Photograph 5-6). There is a minaret with a single balcony at the northwestern corner (Photograph 7, 8,9). The courtyard walls of the mosque have been built later. The plan and cross section have been shown in Drawings 11 and 12.

The narthex of the mosque has two porticos much like the Üsküdar Mihrimah, Atik Valide and Eminönü Rüstem Paşa Mosques which are other structures by Sinan (Photograph 8). The southern section of the narthex is covered by five domes with pendentives supported by six marble columns and sharp arches on the northern wall. The dome at the entrance axis is larger than the other domes. The sides of this section of the narthex are open. The southern section of the narthex has been encompassed in a $U$ shape by the second narthex. This portico made by sharp arches on 24 columns is covered by a hipped 
roof resembling a lean-to (Photograph 8). There is one mihrabiye each on the outer façade of the northern wall of the mosque with one to the east and the other to the west.

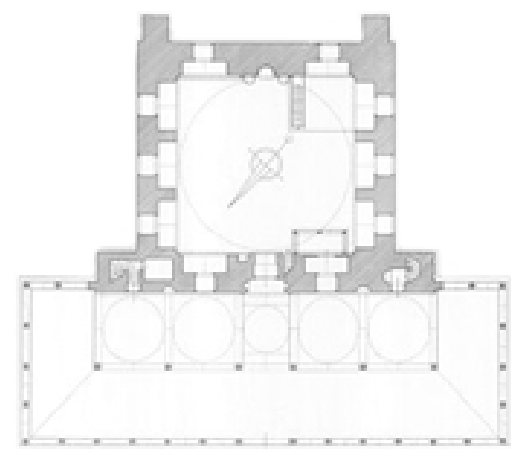

Drawing 11. Kurşunlu Mosque Plan [8]

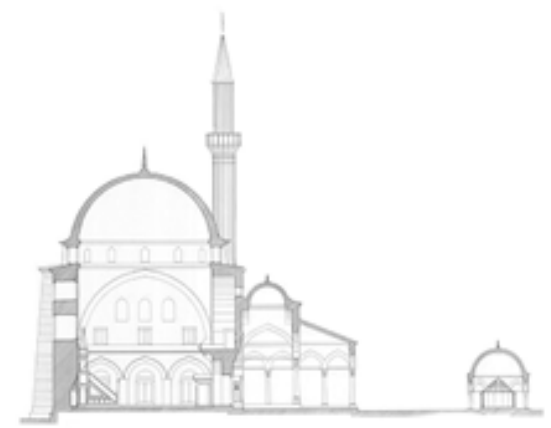

Drawing 12. Kurşunlu Mosque Cross Section [8]

The crown gate of the mosque made of marble has five lines of muqarnas. Two pillars have been placed to the eastern and western façades within the width of the supporting arches carrying the dome in the harim space after which they were connected via lancet arches thus making a gallery surrounding the interior space at all three façades excluding kiblah. The rear side of the crown gate has been protruded inside like two props for supporting these galleries. There are two windows each at the lower sections of the southern and northern walls and three windows each on the eastern and western walls (Photograph 7, 9, 10). These windows have a rectangular form with lancet arch pediments. There are six more windows at the upper section of the southern wall. The same arrangement can be seen on the eastern, western and northern walls. All upper windows are leaded. The mihrab and minbar of the mosque are simple and made of marble. There is a domed fountain in the courtyard supported by lancet arches on eight pillars $[15]$.

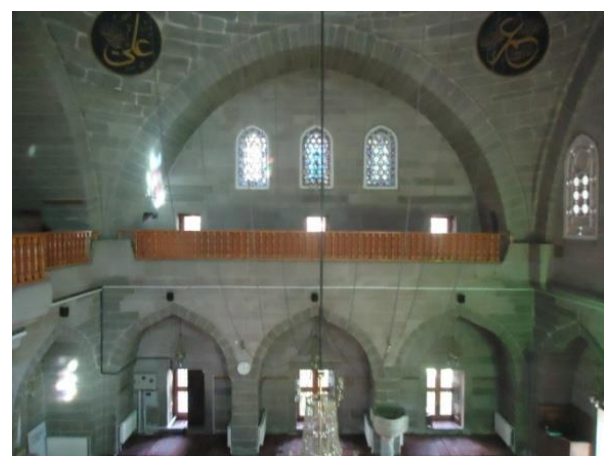

Photograph 5. Kurşunlu Mosque Interior (Merve Hasözhan, 2016)

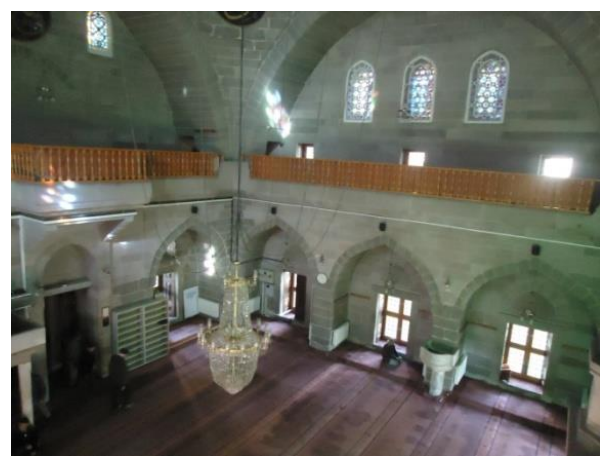

Photograph 6. Kurșunlu Mosque Interior (Merve Hasözhan, 2016) 


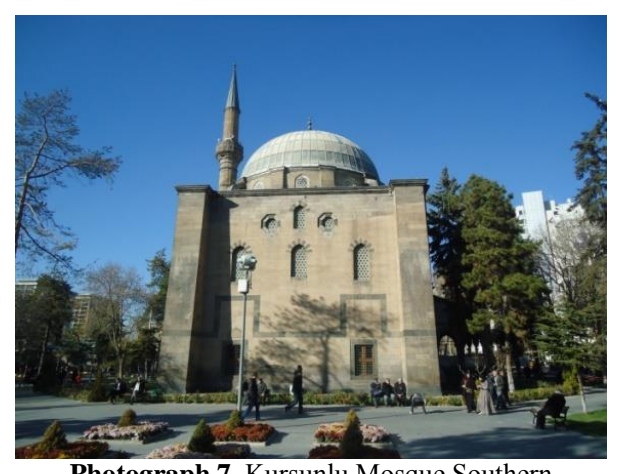

Photograph 7. Kurşunlu Mosque Southern Façade (Merve Hasözhan, 2016)

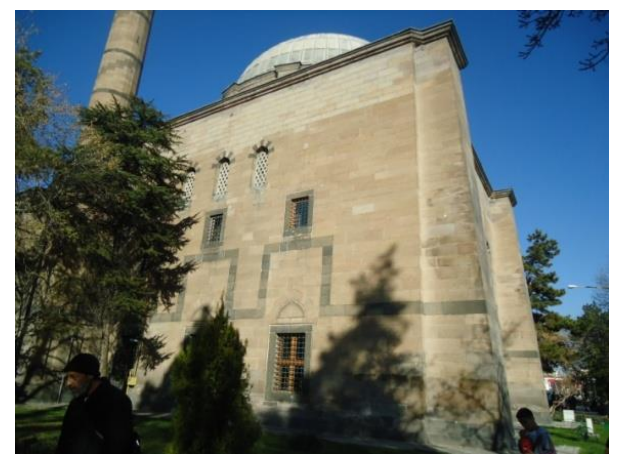

Photograph 9.Kurşunlu Mosque Western Façade (Hürmet Çopuroğlu, 2016)

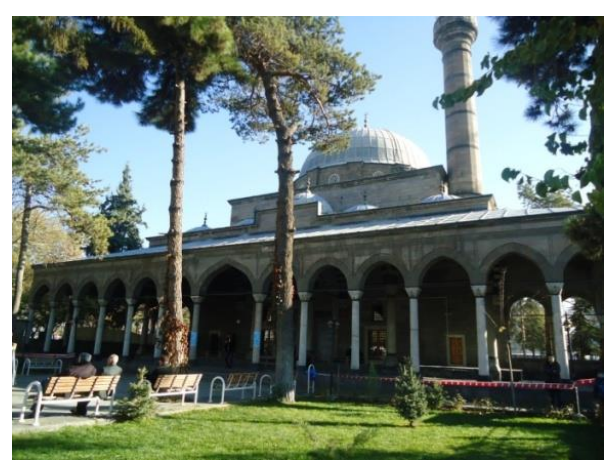

Photograph 8.Kurşunlu Mosque Northern Façade (Hürmet Çopuroğlu, 2016)

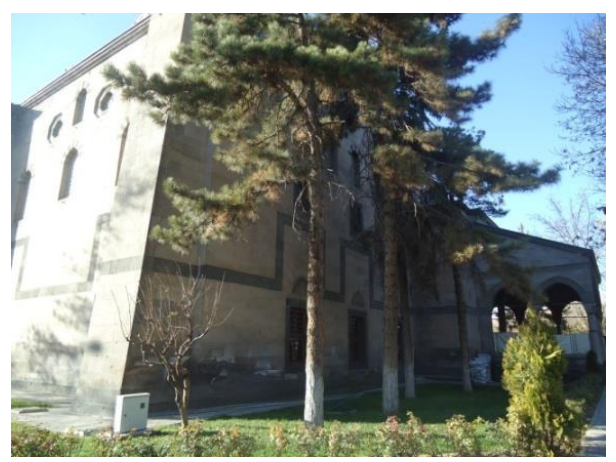

Photograph 10.Kurşunlu Mosque Eastern Façade (Hürmet Çopuroğlu, 2016)

\section{Material and Method}

In this study, Kurşunlu Mosque which is known for its modest appearance representing the characteristics of the 16th century classical period Ottoman architecture was examined rather than the pioneering works by Mimar Sinan during his apprenticeship, qualification and master stages.

Cut stone was considered as the fundamental material for construction when carrying out the approximate cost calculations for the Kurşunlu Mosque. Different materials can be used in mosque structures. These are known as cut stones of different color and texture used for window sills, marble for the two columns of the narthex, crown gate, mihrab and minbar along with lead for the exterior coating of the dome. Cut stone was selected as the material for the study. The reason for selecting cut stone was that it has been used in the main carrier columns of the mosque (Photograph 11). In addition, it is also thought that the dome used as a cover for the mosque has been built of cut stone. However, this section was not included in the calculations. Because, the interior of the dome has decorations, whereas the outer section has lead coating. Only cut stone was considered as the material for the calculations.

Cut stones with different color and dimensions on the outer walls, inner space main carrier columns, trombes and windows have been included in the calculation. In addition, the cut stones parallel to the walls in the interior space which are also located between the carrier arches have also been calculated (Photograph 11, 12, 13, 14, 15, 16). Material item numbers listed in the 2016 unit price list published by the Ministry of Environment and Urbanization were used following the approval from the stone production and manufacturing companies in Kayseri. The total number of cut stones used for the interior space and walls of the Kurşunlu Mosque and their dimensions were determined. Cost was calculated without including labor cost and by multiplying the unit price with the number of cut stones for which the dimensions were also predetermined. 


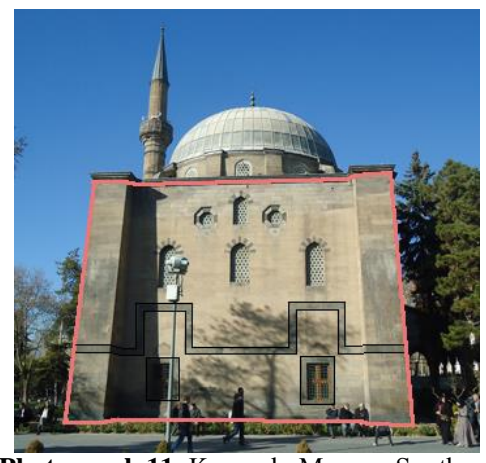

Photograph 11. Kurşunlu Mosque Southern Façade (Merve Hasözhan, 2016)

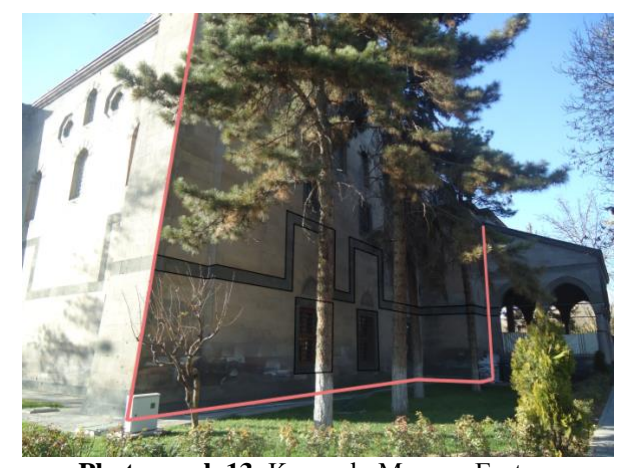

Photograph 13. Kurşunlu Mosque Eastern Façade (Merve Hasözhan, 2016)

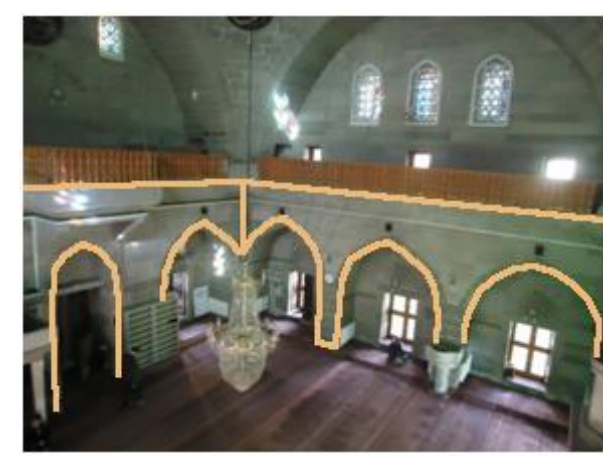

Photograph 15. Kurşunlu Mosque Interior (Hürmet Çopuroğlu, 2016)

Cut Stones at the limited space on the façade

Different colored cut stones on the façade, around the windows

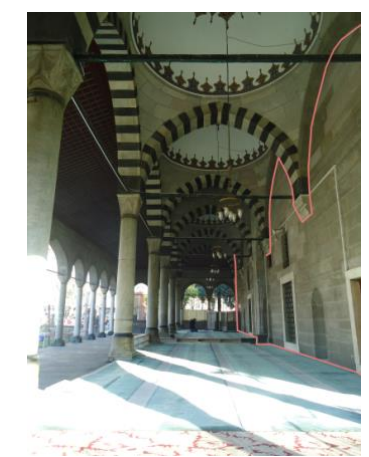

Photograph 12. Kurşunlu Mosque Northern Façade (Merve Hasözhan, 2016)

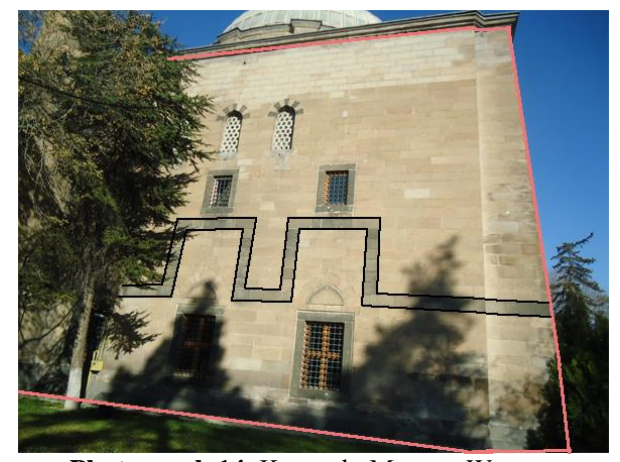

Photograph 14. Kurşunlu Mosque Western Façade (Merve Hasözhan, 2016)

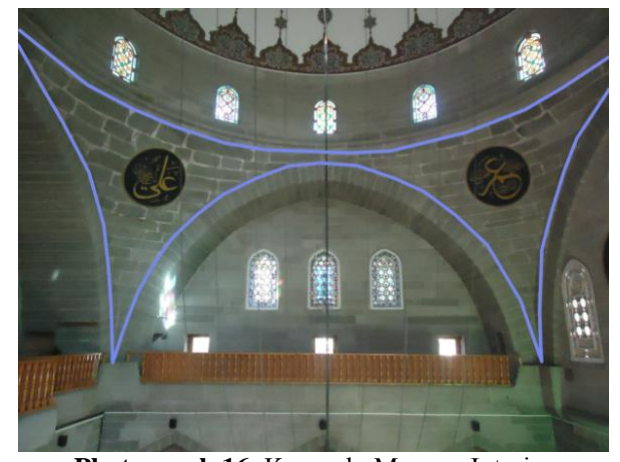

Photograph 16. Kurșunlu Mosque Interior (Hürmet Çopuroğlu, 2016)

Interior columns

Interior trombe section

\section{Cost Analysis for Kurşunlu Mosque Using Current Prices}

It was determined via on-site measurements that cut stones with different dimensions have been used in the mosque. Whereas large stones are used for the lower sections of the mosque walls, the dimensions of the stones used have decreased as we move towards the top sections. It is possible to state two reasons for this difference. The first is that as the mosque walls increased in height, it became easier to place smaller stones. The reason why stones were not selected in decreasing size was that there was no 
problem with regard to carrying and lifting for the technology of the era. Secondly; the aim was to ensure that the size of the mosque should be perceived larger than the perspective as one moved away from the eye level. It was determined as a result of the measurements carried out that thre different stone dimensions have been used with the width constant at $35 \mathrm{~cm}$ and heights varying as; $135 \mathrm{~cm}, 65 \mathrm{~cm}, 35 \mathrm{~cm}$. Counts for the stones included in the measurement for the northern, southern, eastern and western façades along with the interior space were carried out via calculations based on the photographs taken and on-site examinations. The number and dimensions of the stones calculated in this manner have been given in the table below (Table 1).

Table 1. Number and dimensions of the stones used in Kurşunlu Mosque

\begin{tabular}{|c|c|c|c|c|c|c|}
\hline & Northern Façade & Southern Façade & Eastern Façade & Western Façade & Interior Space & TOTAL \\
\hline Large & $165 \mathrm{ad}^{*}$ & 238 ad* $^{*}$ & 382 ad* $^{*}$ & 264 ad* & $128 \mathrm{ad}^{*}$ & $1233 \mathrm{ad}^{*}$ \\
\hline Medium & $60 \mathrm{ad}^{*}$ & $148 \mathrm{ad}^{*}$ & $213 \mathrm{ad}^{*}$ & 128 ad* $^{*}$ & $37 \mathrm{ad}^{*}$ & $586 \mathrm{ad}^{*}$ \\
\hline Small & $171 \mathrm{ad}^{*}$ & $140 \mathrm{ad}^{*}$ & $250 \mathrm{ad}^{*}$ & 356 ad* & $182 \mathrm{ad}^{*}$ & $1099 \mathrm{ad}^{*}$ \\
\hline
\end{tabular}

The width of the stones was taken as a constant of $35 \mathrm{~cm}$ while carrying out the calculations for the number of stones. The 3 different stone sizes determined here were multiplied with their numbers thus determining the total numbers for the small, medium and large sized stones. The numbers determined for each size were multiplied with the unit price listed in the stone material item number in the 2016 unit price list published by the Ministry of Environment and Urbanization thus determining the stone material cost in linear meters. Concurrently, comparison for the unit prices put forth in the legal regulations with those of the market along with required controls were carried out. The definition for the linear meter used for the current construction works is provided as Linear meter is the unit of length used for elements with a certain thickness (a certain area) without taking their widths into consideration.

Table 2 shows the calculated stone material dimension along with the total cost based on the number and unit price. It was determined as a result of the calculations that the cost for the large stones is 91.550,25 TL, cost for the medium sized stones is 20.949,50 TL and cost for the small sized stones is $21.155,75 \mathrm{TL}$. According to these data, the current material cost for the stones used in the construction of the Kurşunlu Mosque is 133.655,5 TL.

Table 2. Calculation of the cost for the stones used in Kurşunlu Mosque

\begin{tabular}{|c|c|c|c|c|}
\hline Stone Size & Dimension & Number & Unit Price & TOTAL \\
\hline Large & $1,35 \mathrm{~m}$ & 1233 & $55 \mathrm{TL}$ & $91.550,25 \mathrm{TL}$ \\
\hline Medium & $0,65 \mathrm{~m}$ & 586 & $55 \mathrm{TL}$ & $20.949,50 \mathrm{TL}$ \\
\hline \multirow[t]{2}{*}{ Small } & $0,35 \mathrm{~m}$ & 1099 & $55 \mathrm{TL}$ & $21.155,75 \mathrm{TL}$ \\
\hline & & & TAL COST & 133.655,5 TL \\
\hline
\end{tabular}

\section{Conclusion}

Construction material is the most important input for a structure which makes it possible to shape the structure and complete its construction. The type of the material used is one of the most important 
factors affecting the cost. Selecting the proper materials from among the alternatives has been and currently is the responsibility of the architect. The efficiency of an architect can be measured by the way he/she reflects the aesthetic elements of the design as well as the suitability and indeed lowness of the resulting costs. There are studies which indicate that all great architects have given special attention to two criteria. It was determined in a study examining the works by Sedad Hakk1 Eldem, an architect with important contributions in modern Turkish architecture, that the architect has selected the materials which emphasize Turkish architecture by taking into consideration the cost of the structure [18]. In another study examining the material cost for the famous structures by famous architects; it was observed that the factor which generally affects the selection of the current materials used in the construction was emphasizing the decisions made during the design stage and that the characteristics of the material were important for this purpose. It was determined that the desired effect was provided by economic materials for these structures in modern architecture [19]. In addition, the Süleymaniye Mosque data in the book entitled "Süleymaniye Mosque Imaret and Its Construction II" by Ömer Lütfi Barkan along with data regarding general cost were taken into consideration for the Kurşunlu Mosque calculations [20]

Sinan has continuously developed and put forth his architectural design and engineering knowledge in all periods as one of the most important architects of the Ottoman Period. He has used stone which was the material of the age he lived in as a carrier and façade material with aesthetic concerns. Stones with different colors, textures and sizes have been used in all his works without compromising from the carrying attributes of stones. It is thought that this material was obtained from local sources or that the material was supplied by stone quarries in the vicinity thus heeding material cost as well. The stone material for the Kurşunlu Mosque which was examined in this study shows similarities with this idea. It was observed that the stones used for the construction of the mosque have the color and texture of the local stone materials found in and around Kayseri. Thus, it was observed that Sinan has used cut stone which is the local material of Kayseri in the construction of Kurşunlu Mosque thereby taking into consideration both the material cost and physical conditions of the environment. It was observed that Sinan, as one of the most important architects of all time, was sensitive with regard to material cost as well as in all other areas and that he put forth this sensitivity in Kurşunlu Mosque as well which is one of the smaller scale structures. In this regard, the fact that Mimar Sinan has designed small scale and low cost structures such as Kurşunlu Mosque in addition to large scale and high cost structures such as Süleymaniye Mosque reflects his modest character. It is hoped that the study will contribute to other works related with material cost.

\section{References}

[1] Yılmaz, İ., Dikmen, S., Ü., "Osmanlı Döneminde Kullanılan Yaklaşık Maliyet Tahmin Yöntemleri” 6. Inş̧aat Yönetimi Kongresi, 25-26-27 November, Proceedings Book, 223-233 s, Bursa, 2011

[2] Internet Reference, https://tr.wikipedia.org/wiki/Cami, Date of Access: 18-11-2016

[3] Benian, E., "Mimar Sinan ve Osmanlı Cami Mimarisinin Gelişimindeki Rolü", TUBíTAK Journals, 41-47, ISSN 97-1300-33-80, 2011

[4] Erkman, E., “Ağırnaslı Sinan”, M. Grup Matbacılık, 62 s, Kayseri, 2000 
[5] Internet Reference, www.sehzade.gen.tr, Date of Access: 08.04.2016

[6] Internet Reference, www.tas-istanbul.com, Date of Access: 23-11-2016

[7] Internet Reference, https://tr.wikipedia.org/wiki/Mimar_Sinan\%27\%C4\%B1n_eserleri_listesi, Date of Access: 27-10-2016

[8] Ülgen, A., S., “Mimar Sinan Yapıları”, Türk Tarih Kurumu Yayınları, Ankara, 1989

[9] Internet Reference, https://dome.mit.edu/handle/1721.3/65891, Date of Access: 20-11-2016

[10] Eruyar, S., "Süleymaniye Külliyesi'nin Tarihsel Süreçteki Değişimi”, Republic of Turkey Ministry of Culture and Tourism, Dissertation, Ankara, 2016

[11] Aslan A., "Süleymaniye Cami'nin Yerel Zemin Koşullarına Bağlı Deprem Performansının Değerlendirilmesi", Ylldız Technical University Institute of Science and Technology, Master's Thesis, İstanbul, 2016

[12] Internet Reference, www.suleymaniyecamii.org, Date of Access: 27-10-2016

[13] Köse, A., "Edirne Selimiye Camii'nde Yazının Süsleme Unsuru Olarak Kullanımı", Trakya University Insitute of Social Sciences, Master's Thesis, İstanbul, 2013

[14] Ekinci, Y., "Tarihi Çevre Korumanın Yönetsel Boyutu Ve Yerel Yönetimlerin Sorumlulukları: Selimiye Camii Alan Yönetimi Örneği”, Trakya University Insitute of Social Sciences, Master's Thesis, İstanbul, 2009

[15] Özbek, Y., Arslan, C., "Kayseri Taşınmaz Kültür Varlıkları Envanteri”, Kayseri Büyük Şehir Belediyesi Yayınları, Cilt-I, Aydoğdu Ofset Matbaacılık ve Ambalaj Sanayi Tic. Ltd. Şti., Ankara, 128-131 s, 2008

[16] Parlak Biçer, Z. Ö., Aksoy, Z., Hancı, M., Yıldırım, E., Gün, A., Özata, G.,Başhoroz, M., "Mimari Projelerde Malzeme Seçiminin Maliyete Etkisinin Sedad Hakkı Eldem Yapıları Üzerinden İncelenmesi”, International Science and Technology Conference iste-c Vİenna 2016, 13-15 July, iste-c Proceedings Book, 687-696 s, Vienna, 2016

[17] Parlak Biçer, Z. Ö., İlhan E., Kırmızıgül D., "Determination Of The Importance Of Materials In Structural Cost Via Architectural Project Examples", The International Conference on Civil and Enviromental Engineering ICOCEE-Cappadocia 2015, May 20-23, ICOCEE Proceedings Book, 116 s, Nevsehir, 2015

[18] Barkan, Ö. L., "Süleymaniye Cami İmareti Ve İnşaatı”, Türk Tarih Kurumu Yayınları, Cilt-II, Ankara, 1979 